\author{
ANDRZEJ BATOR \\ ORCID: 0000-0003-4772-7920 \\ Uniwersytet Wrocławski \\ JAKUB ŁAKOMY \\ ORCID: 0000-0002-6655-6787 \\ Uniwersytet Wrocławski
}

\title{
POJECCIOWE UWARUNKOWANIA BADAŃ NAD ZWIĄZKAMI PRAWA I POLITYKI
}

Artykuły prezentowane w pierwszej sekcji niniejszego „Przeglądu Prawa i Administracji" są odpowiedzią przedstawicieli polskiej nauki prawa na zaproszenie skierowane ze strony wrocławskiej Katedry Teorii i Filozofii Prawa do debaty na temat polityczności prawa, prawoznawstwa i praktyki prawniczej. Naszą inicjatywę adresowaliśmy przede wszystkim do środowiska teoretyków i filozofów prawa. Jednak nawet mimo takiego wyjściowego ograniczenia — skądinąd wielce umownego — odpowiedzi na nasze zaproszenie były tak liczne, że z powodów organizacyjnych nie byliśmy w stanie pomieścić w jednym tomie wszystkich przygotowanych artykułów. Zdecydowaliśmy się w tej sytuacji podzielić zgromadzony materiał na dwie części i równolegle opublikować każdą z nich na łamach polskich wydawnictw prawniczych. Dwanaście artykułów, które prezentujemy w tym tomie, to zatem tylko pierwsza część opracowań będących odpowiedzią na nasze zaproszenie. Część drugą, podobną objętością do tej, czytelnik zainteresowany prawniczą problematyką polityczności znajdzie w przygotowywanym numerze „Krytyki Prawa"1.

Pomysł uczynienia problematyki polityczności przedmiotem refleksji teoretyczno- i filozoficznoprawnej nie jest dla naszego środowiska — a dla osób skupionych wokół wrocławskiej Katedry Teorii i Filozofii Prawa w szczególności — czymś nowym. Odnosząc się tylko do naszej wrocławskiej perspektywy, można zauważyć, że w ostatnich kilkunastu latach dochodziliśmy do tej z wielu powodów ważnej, ale i trudnej — problematyki z różnych perspektyw i w odniesieniu do rozmaitych tradycji badawczych. O dwóch przede wszystkim

\footnotetext{
${ }^{1}$ Zob. „Krytyka Prawa. Niezależne studia nad prawem”- projektowany nr 3 za 2020 rok.
} 
warto, jak się wydaje, wspomnieć. Z jednej strony jest to wzrastające zainteresowanie anglosaskim — a dzisiaj już kulturowo i geograficznie właściwie nielimitowanym — nurtem tak zwanych krytycznych studiów nad prawem, w którego ramach polityczność prawa we wszelkich jego wymiarach badawczych czy decyzyjnych niejako wydobywana jest z pozornie (oficjalnie) neutralnych prawniczych postaw, deklaracji metodologicznych czy programów. Tradycyjne, analityczne teorie prawa, w szczególności uprawiane w nurcie rekonstrukcjonistycznym, z liberalną aksjologią w tle — a takie zdawały się zyskiwać przewagę w polskim prawoznawstwie jeszcze do lat dziewięćdziesiątych — znakomicie nadawały się na przedmiot „filozofii/hermeneutyki podejrzeń”, poszukujących sprzeczności między deklarowanymi scjentystycznymi programami badawczymi a rzeczywistą praktyką prawodawczą czy interpretacyjną. Rozliczne lewicujące nurty z kręgu tak zwanych krytycznych studiów nad prawem i prawoznawstwem dawały solidne podstawy programu takiego „odczarowywania” zastanego, a dominującego w kulturze Zachodniej, sposobu myślenia o prawie. Tylko we wrocławskim ośrodku Teorii i Filozofii Prawa w ramach tej orientacji badawczej podejmowane były między innymi takie obszary problemowe, jak prawo konstytucyjne i konstytucjonalizm (A. Sulikowski), sądowe decyzje orzecznicze i ich legitymizacje (R. Mańko) czy wykładnia prawa i jej współczesne teorie (M. Stambulski i J. Łakomy).

Druga perspektywa wrocławskich badań nad politycznością wyrosła z samej tradycji analitycznej, z pewnej niezgody na dominujący wcześniej tak zwany logocentryczny paradygmat jej uprawiania, skupiony głównie na formalnym wymiarze języka prawnego i prawniczego. O ile nurty krytyczne przyjęły pozycję zewnętrzną wobec zastanego dorobku analitycznej teorii prawa, o tyle perspektywa druga miała bardziej złożone uwarunkowania. Była pewną próbą obrony głównych założeń teorii analitycznych, akceptowała opartą na dorobku dogmatyki prawa konieczność badań językowych, w tym uznających potrzebę tradycyjnych badań logicznych, jednak z mocnym programem ich rozszerzania, otwierania się również na pragmatykę języka kształtowaną pod wpływem impulsów z otoczenia społecznego. W tej perspektywie - można ją nazwać wewnętrzną — otworzyła się też przestrzeń do argumentacji politycznej i polityczności oraz ich relacji wobec prawa i prawoznawstwa. To z takich właśnie źródeł wypłynął koncept tak zwanej postanalitycznej filozofii prawa (A. Bator, M. Paździora, M. Stambulski). Wydawniczym śladem tej orientacji badawczej była publikacja z 2015 roku — także na łamach wrocławskiego „Przeglądu Prawa i Administracji” ${ }^{2}$ — z szerokim już jednak udziałem również innych przedstawicieli polskiej teorii i filozofii prawa.

2 Postanalityczna filozofia prawa, red. M. Jabłoński, M. Paździora, „Przegląd Prawa i Administracji” 102, 2015. Zarysowane w przywołanym tomie propozycje poprzedzone były krytyczną diagnozą stanu teorii prawa, którą zaprezentowaliśmy w zbiorowej monografii Czy koniec teorii prawa?, red. P. Jabłoński, „Prawo” 312, 2011. Postanalityczna filozofia prawa doczekała się również swojej zmodyfikowanej i poszerzonej wersji angielskiej — zob. A Post-Analytical Approach to Philosophy and Theory 
Wcześniej nieco „lokalne” zainteresowanie problematyką polityczności prawa i prawoznawstwa udało nam się w przenieść już w pełni na wymiar ogólnokrajowy propozycją tematyczną XXII Zjazdu Polskich Katedr Teorii i Filozofii Prawa („Prawo - polityka - sfera publiczna”), który miał miejsce we Wrocławiu w 2016 roku, a którego pokłosiem było kilka kolejnych tomów „Przeglądu Prawa i Administracji" ${ }^{3}$ oraz publikacji w innych wydawnictwach afiliowanych przy Wydziale Prawa, Administracji i Ekonomii Uniwersytetu Wrocławskiego ${ }^{4}$. Obecnym tomem postanowiliśmy podjąć raz jeszcze, a może po prostu kontynuować, problematykę związków polityki/polityczności z prawem, praktyką prawniczą i nauką prawa. Czy warto? Naszym zdaniem — zdecydowanie tak. Otworzenie się na wymiar krajowy dostarczyło nowych impulsów dotychczasowej debacie. Po pierwsze, ujawniło nowe kierunki argumentacji, na przykład oparte na republikańskiej interpretacji idei wspólnoty politycznej, znajdujące alternatywne uzasadnienia/legitymizacje prawa i praktyki prawniczej wobec tradycji analitycznej, nawet jeśli miałyby one prowadzić do antyprawnych postaw jak w teorii (teologii) C. Schmitta. Zauważmy tylko na marginesie, że ten ostatni kierunek miał sporo wspólnego z niektórymi postawami lewicującymi — na przykład dystynkcja na „wroga” i „przyjaciela”, podobnie zresztą lokalizująca swojego ideologicznego przeciwnika w liberalnej wizji porządku prawnego.

Powód drugi to znaczące rozszerzenie prawniczych dziedzin badawczych, do których aplikowane są przyjmowane koncepty polityki i polityczności. Już tylko przegląd spisu treści niniejszego tomu ujawnia takie nowe dla wielu z nas obszary badawcze, jak zagadnienia manipulacji ,publiczną prawdą” w warunkach technologicznej rewolucji i jej wpływ na ochronę praw i wolności obywatelskich (K. Dobrzeniecki), strategie rządzenia realizowane przez normalizację procesów biologicznych (K. Gregorczuk), zwrócenie uwagi na kwestię polityczności legislatorów — nie zawsze dostrzeganego komponentu polityki prawodawczej (M. Kłodawski) czy kwestie politycznych uwarunkowań tak wrażliwych obszarów aktywności człowieka, jak intymność i sumienie (P. Sut, M. Łaszewska-Hellrieger).

I jeszcze jeden powód, ogólniejszej natury, który sprawia, że nie tylko warto, ale wręcz należy zajmować się obecnie zagadnieniami związków prawa i prawoznawstwa z polityką. Mamy na tu uwadze współczesną tak zwaną realpolitik. Wszystkie przywołane nurty inspirujące do badań nad związkami prawa i praw-

of Law, red. A. Bator, Z. Pulka, „Polish Contemporary Philosophy and Philosophical Humanities” 14, Berlin 2019.

3 Polityczność nauki prawa i praktyki prawniczej, red. A. Bator, P. Kaczmarek, „Przegląd Prawa i Administracji” 110, 2017.

${ }^{4}$ Prawo $i$ polityka $w$ sferze publicznej. Perspektywa wewnętrzna, red. P. Jabłoński, J. Kaczor, M. Pichlak, „Prace Naukowe Wydziału Prawa, Administracji i Ekonomii Uniwersytetu Wrocławskiego. e-Monografie" 107, Wrocław 2017; oraz Prawo i polityka w sferze publicznej. Perspektywa zewnętrzna, red. P. Jabłoński, J. Kaczor, M. Pichlak, „Prace Naukowe Wydziału Prawa, Administracji i Ekonomii Uniwersytetu Wrocławskiego. e-Monografie” 113, Wrocław 2018. 
ników z polityką — orientacji postanalitycznej nie wyłączając — przyjmują jakiś, mniej lub bardziej zaangażowany, wariant takiej zależności. Byłoby w takiej sytuacji czymś niezrozumiałym, aby abstrahować od otaczającej nas hic et nunc rzeczywistości. Poststrukturalistyczna teza o zacieraniu się podziału na opisowy i normatywny wymiar twierdzeń nauki przestaje być obecnie elementem sporu metodologicznego. Jest - a dowodzą tego wszystkie zamieszczone w prezentowanym tomie teksty — częścią rzeczywiści, realnej praktyki naukowej. To nie pierwszy w historii nauki przypadek, gdy zawiłe spory toczone na łamach naukowych czasopism i w salach konferencyjnych tracą swoją ważność w obliczu rzeczywistości, z którą konfrontuje się nauka. Debata o polityczności prawa, prawoznawstwa i praktyki prawniczej wydaje się obecnie wystawiona na taką właśnie próbę.

Prezentowane w niniejszym tomie teksty, choć tematycznie, problemowo i warsztatowo zróżnicowane, łączy jednak pewna w miarę spójna perspektywa używanego języka. Daje się ona wpisać w pojęciowy trójkąt rozumienia polityki/ polityczności, którego skrajnymi punktami są: (1) arystotelesowskie państwo jako zaangażowana we wspólne wartości wspólnota polityczna, (2) weberowska polityka pojmowana jako celowa działalność zmierzająca do zdobycia i sprawowania władzy publicznej i wreszcie (3), wspomniana już schmittowska (i aplikowana na potrzeby postaw lewicowych przez Ch. Mouffe, E. Laclau i innych) polityczność z jej dystynkcją na „,wroga” i „przyjaciela”, postrzegana w mniej lub bardziej głębokiej strukturze badanego zjawiska społecznego lub twierdzenia naukowego. W prezentowanych tekstach ilościowo zdaje się wyraźnie dominować ostatni z tej triady punkt spojrzenia na prawo/prawoznawstwo i politykę. U niektórych autorów poglądy pary Schmitt-Mouffe — z akcentem na tę drugą postać — są jedynym lub dominującym punktem oparcia prowadzonych rozważań (P. Sut, J. Srokosz). U P. Kaczmarka punktem wyjścia są rozważania M. Webera i jego opresyjne wobec prawa pojmowanie polityki, jednak z silnym kontrapunktem ze strony wewnętrznych wartości prawa (praworządność, trójpodział władzy). Prowadzi to do pozycjonowania prawa w opozycji wobec tak rozumianej polityki. M. Kłodawski deklaruje z kolei akces w stronę konceptów Ch. Mouffe, niemniej jednak w sposobie argumentacji autora dostrzec można również ślady weberowskiej koncepcji władzy, chociażby przez przywoływanie zagrożeń, jakie opisywane przez obie te koncepcję zjawiska mogą stwarzać dla współczesnych legislatorów. Do zbliżonych identyfikacji pojęciowych prowadzi lektura opracowań przygotowanych przez M. Łaszewską-Hellrieger, M. Wojciechowskiego oraz B. Nalezińskiego i J. Holocher. Natomiast arystotelesowski punkt oparcia w pojmowaniu władzy politycznej (w mocnej adaptacji psychoanalitycznej) reprezentuje praca M. Romanowicza. Tego samego patrona dla swoich rozważań obrał również w swoim spojrzeniu na rolę prawdy w życiu publicznym K. Dobrzeniecki. Władza postrzegana jako zarządzanie procesami życia i zdrowia człowieka (biowładza) opisywana w artykule K. Grzegorczuka zdaje się z kolei wyłamywać poza przywołaną triadę, 
a może po prostu znajduje związki z każdym z jej elementów. Nie podejmujemy się tego w tym miejscu rozstrzygać. Mimo zatem naturalnego dla prac zbiorowych zróżnicowania problemowego, przyjmowanych postaw badawczych czy sympatii filozoficznych prezentowany zbiór tekstów zaskakująco wiele zdaje się łączyć.

$\mathrm{Na}$ odrębną, ale w pewnym tylko stopniu, charakterystykę zasługują naszym zdaniem artykuły przygotowane przez P. Jabłońskiego i W. Zomerskiego. Odmienność ta powodowana jest przyjętą przez piszących strategią argumentacyjną. Autorzy odwracają bowiem kolejność swojej argumentacji: nie wychodzą od tez ugruntowanych $\mathrm{w}$ dostępnych teoriach polityki i polityczności, ale od (wydawałoby się) aksjologicznie neutralnych prawniczych teorii analitycznych - W. Zomerski od dominującej w okresie PRL-u teorii dogmatyki, a P. Jabłoński od założeń pewnej analityczno-hermeneutycznej koncepcji wykładni (mowa o poziomowej koncepcji interpretacji tekstu prawnego). Proponowane w każdym z tych tekstów rekonstrukcje ostatecznie prowadzą do jakiejś bardziej (W. Zomerski) lub mniej (P. Jabłoński) politycznej interpretacji badanych teorii prawniczych. Dla pierwszego jest to krytyka ówczesnej teorii dogmatyki jako efektu celowej separacji nauki od politycznego otoczenia wraz z postulatem - odpowiadającym programowi postanalityczności - budowania responsywnej wobec otoczenia politycznego koncepcji dogmatyki prawa. Dla drugiego z kolei jest to ujawnianie - w tonie aprobaty - wymiaru ideologicznego leżącego u podstaw omawianej teorii wykładni. Znajdujemy tu zatem procedurę argumentacyjną opartą na programie wewnętrznej reorientacji wybranych fragmentów dorobku analitycznej teorii prawa: od politycznie neutralnej nauki do odkrywania i uznawania potrzeby jej aksjologicznego zaangażowania.

Rzeczywista polityka może być dobra i zła. I już z tego powodu w pewnych sytuacjach warto szukać granic ingerencji polityki w prawo czy - w granicach rozsądku - bronić autonomii prawa i prawoznawstwa. Polityka ujęta w reżim warsztatu badawczego nie jest już ani dobra, ani zła. Ignorowanie lub uwzględnianie politycznego uwikłania prawa i praktyki prawniczej może tylko zawężać lub rozszerzać przestrzeń naszego naukowego poznawania. Politykę można różnymi językami nazywać (na przykład politologiczną ideologią lub analityczną presupozycją). Tym, czego na pewno nie powinniśmy czynić, jest oddzielenie polityki jako perspektyw spojrzenia na prawo. Taka próba oznaczałaby bowiem separację nauki prawa od jej przedmiotu badawczego. Temu ostatniemu obce są bowiem dystynkcje na to, co polityczne i apolityczne.

Środowiskowe, metodologiczne, a przede wszystkim problemowe rozszerzanie się prawniczych badań nad polityką i politycznością niesie z sobą organiza- 
cyjne konsekwencje, które dobrze znają redaktorzy wszelkich opracowań zbiorowych. Chodzi oczywiście o tematyczną i warsztatową spójność proponowanego zestawu tekstów. Da się ją w tego typu opracowaniach utrzymywać zawsze tylko w pewnych, tolerancyjnie zazwyczaj interpretowanych, granicach. W wypadku prezentowanych tekstów organizatorzy niniejszego przedsięwzięcia nie mieli trudnego zadania. Przygotowane opracowania, choć z natury rzeczy wielotematyczne i operujące na różnych poziomach pojęciowej abstrakcji, to jednak — w naszej ocenie - prezentują w miarę koherentną całość. Przy ich lekturze, jak już wspomnieliśmy, łatwo zauważyć pewną wspólnotę myślenia i rozprawiania o związkach prawa z polityką. Dają tu znać o sobie wspólne lektury i poglądy nierzadko wcześniej przedyskutowane przy innych okazjach. Być może skromnym wkładem organizatorów niniejszego przedsięwzięcia w tę kierunkową spójność były pewne „podpowiedzi” wyznaczające elementy języka proponowanej debaty, które skierowaliśmy do autorów. Miały być one pewną limitującą ich, a być może po części również inspirującą, „mapą” do ich poszukiwań badawczych. Mamy nadzieję, że również czytelnikom dostarczą pojęciowych narzędzi, które pozwolą na lepszą orientację $\mathrm{i}$ interpretację $\mathrm{w}$ problematyce obecnej w prezentowanych tekstach.

„Polityczność” oznacza dla nas bowiem propozycję, aby głównym przedmiotem debaty uczynić polityczne uwikłania (bądź brak uwikłań) zarówno samego prawa, jak i nauki prawa. W ślad za literaturą przedmiotu proponujemy użyty tu termin rozumieć na trzy podstawowe sposoby. Wyznaczają one trzy główne (oczywiście tylko orientacyjne) obszary tematyczne, w ramach których poruszają się autorzy w niniejszym tomie.

Po pierwsze, mamy na myśli polityczność rozumianą jako antagonizm leżący u podstaw każdego społeczeństwa, a obecny w tak zwanej strukturze głębokiej prawa, teorii prawa i dogmatyki prawa (polityczność rozumianą jako the political). Po drugie, polityczność w znaczeniu politics — zestawu praktyk i instytucji, które w obliczu wprowadzonego przez polityczność w pierwszym znaczeniu konfliktu tworzą porządek umożliwiający ludzkie współistnienie. Po trzecie wreszcie, polityczność w rozumieniu policy, czyli określonego zbioru zasad, których przyjęcie ma umożliwić osiągnięcie wybranego uprzednio celu (na przykład „polityka rolna”, ,polityka obronna”)

Zakładamy, w zgodzie z poglądami prezentowanymi w literaturze, że polityczności prawa i nauki prawa nie powinno się badać bez uwzględnienia faktu, że dominujące współcześnie nurty badawcze przyjmują określone (bardziej lub mniej jawne) założenia dotyczące relacji prawa i polityki. Aby uchwycić złożone

${ }^{5}$ Ch. Mouffe, Polityczność, Warszawa 2008, s. 24 - rozróżnienie politics i the political. Trzeci element — policy pojawił się w J. Łakomy, Polityczność (teorii) wykładni prawa: perspektywa neopragmatyzmu Stanleya Fisha, „Archiwum Filozofii Prawa i Filozofii Społecznej” 2018, nr 3, s. 24-37, http://archiwum.ivr.org.pl/2546/politycznosc-teorii-wykladni-prawa-perspektywa-neopragmatyzmu-stanleya-fisha/ (dostep: 5.09.2020); R. Mańko, W stronę krytycznej filozofii orzekania. Polityczność, etyka, legitymizacja, Łódź 2018, s. 147 n. 
relacje między prawem i polityką oraz refleksją teoretyczną i doktrynalną nad prawem, możemy spojrzeć na trzy odmienne aspekty tego zagadnienia: statyczny, dynamiczny oraz epistemologiczny. Pomoże to lepiej naświetlić zagadnienie polityczności prawa i nauki prawa w opublikowanych w niniejszym tomie tekstach.

Aspekt statyczny relacji prawa i polityki dotyczy tego, w jaki sposób nauka prawa postrzega obecność polityczności w ramach samego prawa. Należy tutaj wyraźnie podkreślić, że „zawartość prawa”, znaczenie norm, merytoryczna „zawartość" norm prawnych może być w większym lub mniejszym stopniu upolityczniona. Co ważne, owo „upolitycznienie” może dotyczyć zarówno politics, the political, jak i policy. Przeprowadzając analizę (a)polityczności prawoznawstwa w tym aspekcie, należy poddać pod rozwagę, jak tę relację ujmuje dany nurt jurysprudencji. Aspekt ten można nazwać ontologicznym, ale naturalnie pozostaje on w ścisłym związku z pozostałymi dwoma aspektami ${ }^{6}$.

Aspekt dynamiczny natomiast skupia naszą uwagę na procesie legislacyjnym i udziale w nim prawników-ekspertów, w tym naukowców. Patrząc na relację prawa i polityki w tym aspekcie, konceptualizujemy proces legislacyjny jako swoiste przedłużenie procesu politycznego. Należy tutaj zwrócić uwagę na uczestniczenie przedstawicieli jurysprudencji w tym procesie i wpływ tego zjawiska na polityczność prawa ${ }^{7}$.

Aspekt epistemologiczny zaś dotyczy tego, jaki rodzaj i zakres materiałów badawczych może być wykorzystywany w procesie poznawania zjawiska prawa. Dotyczy to na przykład możliwości wykorzystania materiałów legislacyjnych czy wypowiedzi polityków przy stanowieniu prawa ${ }^{8}$.

Mauro Zamboni, wziąwszy pod uwagę trzy wskazane aspekty relacji prawa i polityki, wyróżnia dodatkowo trzy „modele” („typy idealne”) tej relacji: autonomiczny, „wbudowany” oraz „krzyżujący się”.

Model autonomiczny odnajdziemy głównie w analitycznej jurysprudencji i pozytywizmie prawniczym ${ }^{9}$. Nurty te ujmują prawo i politykę jako autonomiczne, niezależne fenomeny. Model „wbudowany” zakłada, że prawo jest „podrzędne”, „wbudowane” w sferę polityczności. Zamboni jako przykłady tego modelu wymienia i opisuje ruch studiów krytycznych nad prawem, prawo natury oraz Law and Economics, a więc ruchy, które prima facie nie mają z sobą zbyt wiele wspólnego ${ }^{10}$. Model „krzyżujący się"11 z kolei odnajdujemy w najróżniejszych odmianach realizmu prawniczego. Prawo i polityka miałyby w nim tylko część punktów wspólnych.

${ }^{6}$ M. Zamboni, Law and Politics. A Dilemma for Contemporary Legal Theory, Berlin 2008, s. 5 .

\footnotetext{
7 Ibidem, s. 7.

8 Ibidem, s. 8.

9 Ibidem, s. 19.

10 Ibidem, s. 49.

11 Ibidem, s. 83.
} 
Należy także zauważyć, że polityczność jest czasami traktowana zarówno jako cecha samego prawa (bądź też systemu prawa), jak i założenie przyjmowane przez jurysprudencję. Takie ujęcie problemu odnajdziemy w ogólnej refleksji nad prawem, która ma swoje źródła w filozofii krytycznej. Jak wskazywali Rafał Mańko i Jakub Łakomy:

Pierwszym i fundamentalnym, jak się wydaje, założeniem co do ontologii społecznej podzielanym przez wszelkie nurty krytycznej nauki prawa, od klasycznych (amerykański ruch Critical Legal Studies) po rozmaite odmiany powstałe później (krytyczna teoria rasowa, jurysprudencja feministyczna), a nawet włączając nurty pozostające na marginesie głównego nurtu krytycznej nauki prawa (jak krytyczna socjologia prawa nawiązująca do założeń metodologicznych P. Bourdieu), jest założenie o polityczności świata społecznego. Pojęcie „polityczności” rozumieć tu należy za C. Schmittem, Ch. Mouffe i E. Laclau oraz autorami do nich nawiązującymi (jak S. Žižek, A. Sulikowski czy M. Paździora i M. Stambulski) nie jako prosty związek z polityką czy zdeterminowanie przez politykę, ale jako wymiar nieusuwalnego konfliktu przeszywający społeczeństwo. Założenie o polityczności świata społecznego oznacza więc, że konflikt jest wpisany we wszelkie zjawiska społeczne i nie może on być w sposób ostateczny usunięty. Społeczeństwo jest więc niejako skazane na konflikty i konieczne jest wypracowanie mechanizmów ich instytucjonalizacji, nie jest natomiast możliwa ich likwidacja (niemożliwe jest tzw. społeczeństwo harmonijne, pozbawione wszelkich konfliktów ${ }^{12}$.

Bardzo silny związek prawa i polityki jest zauważany również przez autorów w ramach paradygmatu postanalitycznego. Ów związek jest dostrzegany zarówno na poziomie ontologii, jak i nauki prawa. Jak pisze Andrzej Bator:

Pojawieniu się spectrum postaw identyfikowanych z postanalitycznością mogą również towarzyszyć pewne obawy. Przywołam tylko dwie. Pierwsza to niebezpieczeństwo upolitycznienia nauki, co w przypadku prawoznawstwa ma szczególny ciężar gatunkowy. Polityczność w kulturze prawa stanowionego zawsze silnie legitymizowała prawotwórstwo, jednak stosowanie prawa, z lepszym bądź gorszym skutkiem, usiłowano od polityki uniezależnić. Dorobek analitycznej teorii prawa dobrze służył separacji naukowej i zawodowej praktyki prawniczej wobec bieżącej polityki. W rozważaniach przedstawicieli nurtu postanalitycznego aktywności zawodowej prawnika, także prawnika akademickiego, od polityki już odseparować się nie da. Więcej, polityczność zdaje się tu świadomie powracać do nauki jako społecznie ważny wymiar egzystencji grup i jednostek ${ }^{13}$.

Co więcej, choć prima facie przedstawiciele pozytywizmu prawniczego i jurysprudencji analitycznej nadal utrzymują, że teza o źródłach oraz teza o separacji sprawiają, że zarówno pojęciowa, jak i praktyczna separacja prawa i polityczności jest możliwa, to bardzo często również uznają, że przy bliższej analizie relacja prawa i polityki jest problematyczna. Jak zauważa Tomasz Gizbert-Studnicki:

Skoro [...] przedsięwzięcie, którego podejmuje się filozofia polityczna, ma charakter normatywny (bez względu na to, czy jest uprawiana w duchu realizmu, czy też w duchu moralizmu), natomiast pozytywistyczna teoria prawa swoją tożsamość określa przez wskazanie na deskryp-

12 R. Mańko, J. Łakomy, W poszukiwaniu presupozycji ontologicznych krytycznej nauki o prawie, „Krytyka Prawa” 10, 2018, nr 2, s. 454-455.

13 A. Bator, Postanalityczna teoria i filozofia prawa. Nowe szanse, nowe zagrożenia, „Przegląd Prawa i Administracji” 102, 2015, s. 42-43. 
tywność, to na pierwszy rzut oka relacja między tymi dyscyplinami wydaje się prosta: nie ma pomiędzy nimi żadnych istotnych związków, a w szczególności pozytywistyczna teoria prawa może być uprawiana w całkowitym oderwaniu od filozofii politycznej. Co najwyżej teoria prawa może mieć pewne znaczenie dla filozofii politycznej, zwłaszcza uprawianej w duchu realizmu, poprzez dostarczanie tej drugiej dyscyplinie informacji i wyjaśnień dotyczących rzeczywistych właściwości i sposobów funkcjonowania prawa ${ }^{14}$.

Teksty zebrane w niniejszym tomie „Przeglądu Prawa i Administracji” posługują się wszystkimi trzema zarysowanymi powyżej rozumieniami ,polityczności” (the political, politics, policy); zajmują stanowiska w ramach wszystkich trzech modeli (autonomiczny, „wbudowany”, „krzyżujący się”), a także dostrzegają każdy z trzech aspektów relacji prawa i polityki (statyczny, dynamiczny, epistemologiczny). Taka konceptualizacja problematyki relacji polityczności i prawa oraz nauki prawa w artykułach w tym tomie pokazuje, jak wielowymiarowy i złożony jest to problem.

14 T. Gizbert-Studnicki, Filozofia polityczna a pozytywistyczna teoria prawa, „Przegląd Prawa i Administracji” 110, 2017, s. 42-43. 